https://helda.helsinki.fi

\title{
The fractal lightning burn results from a positively charged strike
}

\section{Nijsten, Maarten}

2017-08

Nijsten , M , Lindford, A , Vuola , J \& Kankuri , E 2017 , ' The fractal lightning burn results from a positively charged strike ' , Intensive Care Medicine , vol. 43 , no. 8 , pp. 1167-1168 . https://doi.org/10.1007/s

http://hdl.handle.net/10138/237244

https://doi.org/10.1007/s00134-017-4816-y

publishedVersion

Downloaded from Helda, University of Helsinki institutional repository.

This is an electronic reprint of the original article.

This reprint may differ from the original in pagination and typographic detail.

Please cite the original version. 


\title{
CORRESPONDENCE
}

\section{The fractal lightning burn results from a positively charged strike}

\author{
Discussion on "Resuscitated unconscious male: Lichtenberg's sign lighting the way"
}

Maarten Nijsten ${ }^{1 *}$, Andrew Lindford $^{2}$, Jyrki Vuola ${ }^{2}$ and Esko Kankuri ${ }^{3}$

๑c 2017 Springer-Verlag Berlin Heidelberg and ESICM

\section{Initial correspondence from Dr. Nijsten}

Dear Editor,

A recent short piece in the "Imaging" section of Intensive Care Medicine reported by Lindford and colleagues describes a patient with so-called Lichtenberg figures [1]. In humans this fascinating pattern has long been known to be pathognomonic for lightning injury. The authors state that the pathogenesis of the markings is unclear and that it would not be a physical phenomenon [1]. This is not true.

In 1975, the revolutionary and highly influential concept of the fractal shapes was formulated by Benoit Mandelbrot of IBM Research [2]. Soon afterwards many research groups recognized the presence of fractal shapes in all sorts of physical and biological systems.

In 1987, we analyzed Lichtenberg figures in lightning victims. In multidisciplinary research that included mathematical modelling, stochastic computer simulation, high-voltage discharge experiments and analysis of Lichtenberg burns, we elucidated the underlying mechanism [3]. The fern-like lesions are first-degree burns with an obviously non-anatomical pattern. The fractal nature of this pattern can be directly explained from a positive lightning strike, which is relatively infrequent as most direct strikes are negatively charged. The fractal shape can only result from a superficial positive discharge because such a discharge attracts the charge carriers, i.e. electrons. A negative discharge that emits electrons has a more deterministic and homogeneous structure and thus a non-fractal structure [3].

\section{Reply from Drs. Lindford, Vuola and Kankuri}

We read the letter from Dr. Nijsten with great interest and would like to thank him for his help in clarifying the actual pathogenesis of Lichtenberg figures (LFs). Their pathophysiology has indeed puzzled and fascinated clinicians and scientists for centuries with various postulated mechanisms described in the literature. Their transient fern-like patterns do not correspond to any anatomical, vascular or neural distribution, and some consider LFs to represent extravasated red blood cells in the superficial skin layer secondary to dielectric skin breakdown and subsequent massive electron shower [4]. Dr. Nijsten and his team demonstrated in 1987 that LFs are fractal patterns resulting from a less common positive lightning strike. They also describe LFs to be a first-degree (superficial) burn that affects only the superficial epithelium [3]. The latter may be supported by their transitory nature and absence of any findings on biopsy [1], but more typically a first-degree burn is characterised by a diffuse area of erythema, in contrast to the precise delicate fern-like pattern of a LF. It is feasible, however, that the erythematous LF pattern derives from a dilated capillary network in the epidermis. It would in fact be interesting to utilize novel tools such as RNA expression profiling [5] or RNA sequencing [6] to reveal molecular level changes in the superficial skin during the course of LF evolution.

Thus, whilst some doubt exists as to whether or not LFs represent a true pathological lesion, they can certainly be considered to be a physical phenomenon pathognomonic for lightning injury.

\footnotetext{
*Correspondence: m.w.n.nijsten@umcg.nl

${ }^{1}$ Department of Critical Care, University Medical Center Groningen, Groningen, The Netherlands

Full author information is available at the end of the article
}

\section{实




\section{Author details}

${ }^{1}$ Department of Critical Care, University Medical Center Groningen, Groningen, The Netherlands. ${ }^{2}$ Department of Plastic Surgery, Helsinki Burn Centre, Töölö Hospital, Helsinki University Hospital (HUS), Topeliuksenkatu 5, P.O. Box 00029, Helsinki, Finland. ${ }^{3}$ Department of Pharmacology, Faculty of Medicine, University of Helsinki, Helsinki, Finland.

\section{Compliance with ethical standards}

\section{Conflicts of interest}

The authors declare that they have no conflict of interest.

Accepted: 22 April 2017

Published online: 15 May 2017
2. Mandelbrot B (1977) Fractals: form, chance and dimension. Freeman, San Francisco

3. ten Duis HJ, Klasen HJ, Nijsten MW, Pietronero L (1987) Superficial lightning injuries - their 'fractal' shape and origin. Burns 13:141-146

4. O'Keefe Gatewood M, Zane RD (2004) Lightning injuries. Emerg Med Clin North Am 22:369-403

5. Nuutila K, Siltanen A, Peura M, Bizik J, Kaartinen I, Kuokkanen H, Nieminen T, Harjula A, Aarnio P, Vuola J, Kankuri E (2012) Human skin transcriptome during superficial cutaneous wound healing. Wound Repair Regen 20(6):830-839

6. Katayama S, Skoog T, Jouhilahti EM, Siitonen HA, Nuutila K, Tervaniemi MH, Vuola J, Johnsson A, Lönnerberg P, Linnarsson S, Elomaa O, Kankuri E, Kere J (2015) Gene expression analysis of skin grafts and cultured keratinocytes using synthetic RNA normalization reveals insights into differentiation and growth control. BMC Genom 25(16):476

\section{References}

1. Lindford A, Vuola J, Kankuri E (2017) Resuscitated unconscious male: Lichtenberg's sign lighting the way. Intensive Care Med. doi:10.1007/ s00134-017-4765-5 